\title{
Water Quality Assessment of a Coastal Canal within a Protected Zone in Algeria using Principal Component Analysis
}

\author{
Lamia Benhalima ${ }^{1,2 *}$, Skander Kadri ${ }^{1}$, Choukri Barour ${ }^{3}$, Mourad Bensouilah ${ }^{1}$ and Rachid Ouzrout ${ }^{1}$ \\ 'Ecobiology Laboratory for Marine Environments and Coastal Areas, Faculty of Sciences, BP 12 El-Hadjar, \\ University Badji -Mokhtar 23000 Annaba, Algeria; \\ Lamia-kos1@hotmail.fr \\ ${ }^{2}$ Department of Biology, Faculty of Science of the Nature and the Life and the Science of the Earth and the \\ Universe, BP 401, Université 8 Mai 1945 Guelma, 24000 Guelma, Algeria; \\ ${ }^{3}$ Laboratory of Terrestrial and Aquatic Ecosystems, Department of Biology, Faculty of Sciences, \\ University Mohamed Cherif Messadia-Souk Ahras, 41000, Algeria; \\ barour_choukri@yahoo.com
}

\begin{abstract}
Objectives/Methods: The effects of human and agricultural activities on waters of Messida canal link up Tonga Lake (RAMSAR site) with the Mediterranean Sea were assessed by determining the fluctuations of indicator of fecal pollution and physico-chemical parameters. The distribution of bacterial pathogens was also monitored. Findings: Most of hydrological parameters show large fluctuations between sampling sites and seasons $(\mathrm{P}<0.05)$. In spring and summer, chlorophyll-a, orthophosphate, BOD5 values were abundant compared to winter values. The nitrate and nitrite concentrations exceeded the guideline for protection of aquatic life. Ammonium, $\mathrm{pH}$, suspended matter, total dissolved matter content does not exceed existing norms. All water samples also had detectable concentrations of five indicators and total viable and active bacteria (TVBC) with log mean \pm standard deviation densities of $6.02 \pm 0.4$ total coliforms (TC), $5.8 \pm 0.4$ fecal coliforms (FC), $5.7 \pm 0.4$ Escherichia coli (EC), $4.6 \pm 0.2$ fecal streptococci (FS), $2.5 \pm 1.4$ sulfito-reducing bacteria (RS), and $6.8 \pm 0.3$ TVBC per $100 \mathrm{ml}$. The results of the statistical analysis (PCA) showed that the presence of fecal indicator is strongly influenced by the oxygen, DBO5 and P04 and to a lesser extent by salinity, $\mathrm{T}^{\circ}$ and $\mathrm{pH}$. A total of 40 species of potential pathogens bacteria were isolated: the most common strains isolated from all samples were Aeromonas hydrophila (70\%). Application: These results demonstrated that the water quality in this region is critical and support a need for better land management practices to protect water quality and aquatic life.
\end{abstract}

Keywords: Fecal Pollution, Messida Coastal Canal, Pathogens Bacteria, Physico-chemical Parameters, Principal Component Analysis, Water Quality

\section{Introduction}

Situated at the interface between fresh- and marine waters, estuaries and coastal canals are among the most biologically productive ecosystems in the world and are of great ecological and economic importance ${ }^{1}$. The

${ }^{*}$ Author for correspondence 
Messida canal represents a rare Mediterranean coastal canal located in a Northeastern wetland of Algeria. The canal is a biological corridor allow exchanges Tonga Lake - Mediterranean Sea, it assure displacement of conger eel and other species of fish. However, the Messida canal is also highly anthropogenically impacted, due to the high activities and intensive agriculture. Seasonal variations in precipitation, surface run-off, animal fecal pollution, have a strong effect on the concentration of pollutants in canal waters.

It is a growing concern that anthropogenic activities are continuously polluting the global water resources 2 . In aquatic environment, agriculture and animal fecal pollution poses significant risk to human and environmental health ${ }^{3.4}$. Today we can consider that the use of the waters of the canal Messida can pose a health risks, because it is used for recreational activities, fishing and irrigation. In addition, the environment of coastal sea may be strongly influenced by the input of pollutants from Messida canal.
The main objectives of this study were (1) to enumerate the fecal indicators in coastal canal discharging to marine waters (2) investigate the influence of some environmental parameters on the abundance of fecal bacteria (3) to understand the hydrologic cycle of Messida canal as a coastal wetland area (4) to investigate the occurrence of Salmonella, Vibrio cholerae, Pseudomonas aeruginosa, and Staphylococcus aureus, and (5) to provide information that helps identify the main pollutants present in the system, and may help in the future to establish specific regulations in order to improve water quality in the area.

\section{Materials and Methods}

\subsection{Site Description and Sampling Sites}

The Messida canal is a coastal canal link up Tonga Lake with the Mediterranean (Figure1). This canal is located

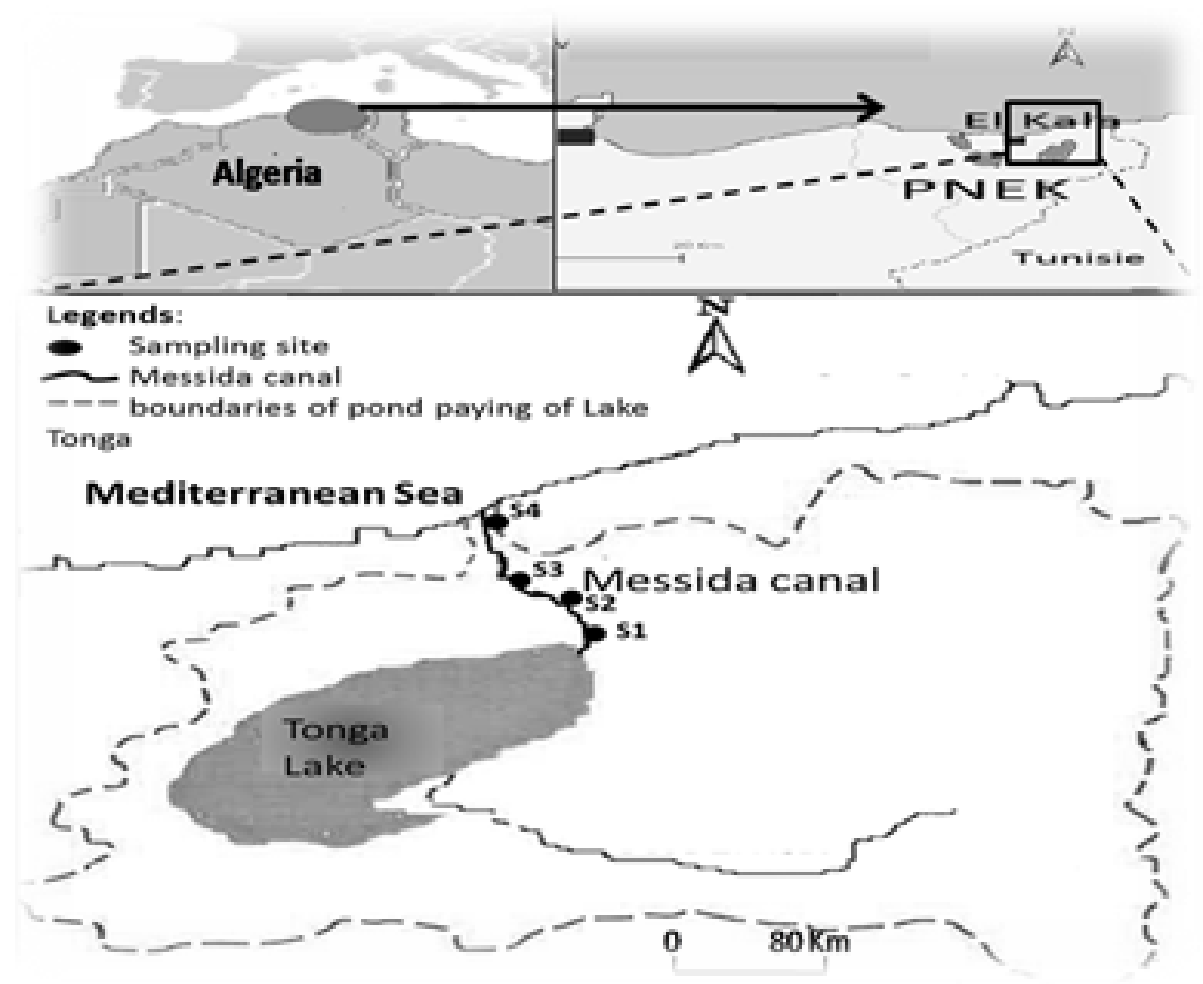

Figure 1. Map of the Messida canal with location of the sampling stations (Map of El Kala National Park Wetlands 'PNEK' adapted from Algerian Ministry of Agriculture, Forestry Department, Braptia Park). 
between $36^{\circ} 53^{\prime} 60 \mathrm{~N}$ and $8^{\circ} 31^{\prime} 0 \mathrm{E}$ in the Northeast of Algeria, its length is approximately $1500 \mathrm{~m}$; the depth of the water column varies between 1 and $2 \mathrm{~m}$ with a maximum of $2.5 \mathrm{~m}$ in the center. The land of the investigated area is agricultural, used for extensive livestock operations (horses, cows, sheep and goats), pasture and crops. During the flood events, the Messida canal play a significant hydraulic and hydrological role, it assures the water level of Tonga Lake.

Four sampling points were used with the objective to cover different degrees of anthropogenic pollution in Messida canal: The first one (S1) was collected upstream canal water (near the Tonga Lake about 100 meters away, and horse stable). The second one (S2) was sampled in section used as an irrigation source point. The third sample (S3) was collected near a pasture area. The fourth station (S4), downstream canal water was sampled at an accessible location near the intersection of the canal and coastal Sea (Figure1).

\subsection{Collection of Samples}

All water samples were taken monthly during a one-year period from September 2010 to August 2011. Samples for nutrients analysis were collected in $1.5 \mathrm{~L}$ rinsed $10 \%$ $\mathrm{HCl}$-washed plastic bottles. Samples for bacteriological analysis were collected in sterilized glass bottles from at least $50 \mathrm{~cm}$ away from the bank, from a depth of approximately $20 \mathrm{~cm}$ below the water surface. All water samples were stored and transported in a cold box kept below $4{ }^{\circ} \mathrm{C}$ and analyzed within 5-6 h of sampling ${ }^{5}$.

\subsection{Physico-chemical Analysis}

Temperature (T), pH, Electrical Conductivity (EC), Total Dissolved Solids (TDS), salinity, saturation in dissolved Oxygen $\left(\mathrm{O}_{2}\right)$, and Dissolved Oxygen (DO) of the collected samples were measured on site with an electric multiparameter (Model Multi 3420). Dissolved oxygen, 5-days Biochemical Oxygen Demand $\left(\mathrm{BOD}_{5}\right)$ was determined using BOD meter WTW BSB Messgerät 602. Suspended Matter (SM), Chlorophyll- $a$ (CLH- $a$ ), dissolved inorganic nutrients (nitrate $\mathrm{NO}_{3}{ }^{-}$, nitrite $\mathrm{NO}_{2}$, ammonium $\mathrm{NH}_{4}{ }^{+}$, orthophosphate $\mathrm{PO}_{4}{ }^{3-}$ ) were analyzed according to the methods described by ${ }^{6}$.

\subsection{Bacteriological Analysis}

The bacteriological analysis for total viable and active bacterial (TVBC), fecal indicators (Total Coliforms (TC), Fecal Coliforms (FC), Fecal Streptococci bacteria (FS), spore-forming anaerobic Sulphite-Reducing bacteria (SR)) and the presence/absence of Salmonella (SAL), Vibrio cholerae (VC), Aeromonas hydrophila (AH), Pseudomonas aeruginosa (PA), and Staphylococcus aureus (SA) were analyzed following the standard methods of 7,8 .

All analyses determinations were performed in triplicate on the monthly samples.

\subsection{Statistical Analyses}

Statistical analyses were carried out using the software (R Development Core Team, 2014 Version 3.1.2) developed by 9 . The normality condition of the distributions was checked beforehand by applying the Shapiro-Wilk. Distributions, being usually of asymmetric time, forced us to choose non-parametric alternatives for the statistical analysis. The correlations between the sets of parameters are evaluated by the non-parametric Spearman correlation coefficient $(r)$ to analyze the intensity of relations between our parameters. The inter-station and inter-month comparisons were performed using the nonparametric Kruskal-Wallis test. Thereafter, we applied a principal component analysis (PCA), using a specialized package called $\frac{10}{}$, to characterize the structure of our five sampling sites and to highlight the contribution of environmental parameters measured on the abundance of dosed germs.

\section{Results and Discussion}

\subsection{Physical-chemical Properties of Messida Canal}

The environmental and chemical data obtained during 
Table 1. Geometric mean values of different physico-chemical parameters of the collected samples (Mean \pm Standard Deviation)

\begin{tabular}{|c|c|c|c|c|c|}
\hline Parameters & sites & Autumn & Winter & Spring & Summer \\
\hline \multirow{4}{*}{$\mathrm{T}\left({ }^{\circ} \mathrm{C}\right)$} & $\mathrm{S} 1$ & $16.55 \pm 2.7$ & $9.02 \pm 2.7$ & $15.45 \pm 1 ; 99$ & $20.11 \pm 0.86$ \\
\hline & S2 & $17.64 \pm 3.58$ & $9.94 \pm 3.58$ & $15.5 \pm 2.14$ & $20.65 \pm 1.17$ \\
\hline & $\mathrm{S} 3$ & $18.05 \pm 3.12$ & $10.56 \pm 3.12$ & $16.43 \pm 1.86$ & $21.73 \pm 1.34$ \\
\hline & $\mathrm{S} 4$ & $18.74 \pm 4.02$ & $10.36 \pm 4.02$ & $16.5 \pm 2.10$ & $22.06 \pm 1.33$ \\
\hline \multirow{4}{*}{$\mathrm{pH}$} & $\mathrm{S} 1$ & $8.22 \pm 0.11$ & $7.84 \pm 0.13$ & $8.21 \pm 0.15$ & $8.41 \pm 0.32$ \\
\hline & $\mathrm{S} 2$ & $8.51 \pm 0.13$ & $7.67 \pm 0.31$ & $8.32 \pm 0.11$ & $8.47 \pm 0.15$ \\
\hline & S3 & $8.42 \pm 0.09$ & $7.38 \pm 0.21$ & $8.18 \pm 0.15$ & $8.38 \pm 0.13$ \\
\hline & S4 & $8.24 \pm 0.07$ & $7.64 \pm 0.16$ & $8.15 \pm 0.17$ & $8.30 \pm 0.3$ \\
\hline \multirow{4}{*}{ DO (mg/l) } & $\mathrm{S} 1$ & $9.28 \pm 0.4$ & $9.63 \pm 0.3$ & $4.97 \pm 0.6$ & $5.32 \pm 0.7$ \\
\hline & $\mathrm{S} 2$ & $9.34 \pm 0.4$ & $9.29 \pm 0.4$ & $5.19 \pm 0.5$ & $5.57 \pm 0.5$ \\
\hline & $\mathrm{S} 3$ & $9.14 \pm 0.28$ & $10.01 \pm 0.74$ & $5.93 \pm 0.11$ & $5.89 \pm 0.51$ \\
\hline & $\mathrm{S} 4$ & $9.74 \pm 0.33$ & $10.27 \pm 0.23$ & $5.97 \pm 0.12$ & $6.66 \pm 0.51$ \\
\hline \multirow{4}{*}{ O2 (\%) } & $\mathrm{S} 1$ & $106.19 \pm 7.8$ & $89.81 \pm 1.47$ & $43.89 \pm 13.2$ & $59.5 \pm 10.03$ \\
\hline & $\mathrm{S} 2$ & $103.1 \pm 6.38$ & $91.66 \pm 5.77$ & $55.86 \pm 2.76$ & $65.69 \pm 4.31$ \\
\hline & $\mathrm{S} 3$ & $104.16 \pm 8.95$ & $95.68 \pm 7.02$ & $65.12 \pm 5.84$ & $68.77 \pm 3.36$ \\
\hline & $\mathrm{S} 4$ & $111.96 \pm 4.95$ & $99.6 \pm 3.5$ & $63.86 \pm 5$ & $80.93 \pm 5.11$ \\
\hline \multirow{4}{*}{ BOD5 (mg/l) } & $\mathrm{S} 1$ & $2.15 \pm 0.07$ & $1.76 \pm 0.73$ & $5.21 \pm 0.16$ & $4.58 \pm 0.54$ \\
\hline & S2 & $2.31 \pm 0.34$ & $1.94 \pm 0.81$ & $5.29 \pm 0.24$ & $4.87 \pm 0.62$ \\
\hline & $\mathrm{S} 3$ & $2.03 \pm 0.18$ & $1.47 \pm 0.48$ & $5.15 \pm 0.06$ & $4.87 \pm 0.7$ \\
\hline & $\mathrm{S} 4$ & $2.01 \pm 0.23$ & $1.68 \pm 0.56$ & $5.05 \pm 0.05$ & $4.34 \pm 0.57$ \\
\hline \multirow{4}{*}{$\mathrm{EC}(\mu \mathrm{S} / \mathrm{cm})$} & $\mathrm{S} 1$ & $368 \pm 115.51$ & $264 \pm 10.16$ & $455.11 \pm 48.55$ & $512.33 \pm 5.81$ \\
\hline & $\mathrm{S} 2$ & $371.67 \pm 114.18$ & $261.67 \pm 13.82$ & $408.78 \pm 139.51$ & $520 \pm 3.84$ \\
\hline & S3 & $370.44 \pm 122.59$ & $236.33 \pm 4.15$ & $463.22 \pm 44.28$ & $527.67 \pm 1.94$ \\
\hline & $\mathrm{S} 4$ & $537.56 \pm 138.5$ & $254.33 \pm 35.84$ & $478.33 \pm 38.13$ & $836.67 \pm 5.12$ \\
\hline
\end{tabular}


Table 1 Continued

\begin{tabular}{|c|c|c|c|c|c|}
\hline \multirow{4}{*}{ Salinity } & S1 & $0.13 \pm 0.05$ & $0.1 \pm 0$ & $0.1 \pm 0$ & $0.2 \pm 0$ \\
\hline & S2 & $0.13 \pm 0.05$ & $0.1 \pm 0$ & $0.1 \pm 0$ & $0.2 \pm 0$ \\
\hline & S3 & $0.13 \pm 0.05$ & $0.1 \pm 0$ & $0.16 \pm 0.05$ & $0.2 \pm 0$ \\
\hline & S4 & $0.27 \pm 0.1$ & $0.1 \pm 0$ & $0.13 \pm 0.05$ & $0.43 \pm 0.1$ \\
\hline \multirow{4}{*}{ TDS } & S1 & $369.67 \pm 117.05$ & $264.67 \pm 9.46$ & $455 \pm 48.65$ & $514.89 \pm 4.54$ \\
\hline & S2 & $371.44 \pm 114.23$ & $261.56 \pm 13.66$ & $461 \pm 45.67$ & $520.67 \pm 3.5$ \\
\hline & S3 & $370.33 \pm 122.61$ & $236.22 \pm 4.1$ & $462.56 \pm 45.02$ & $527.67 \pm 1.94$ \\
\hline & S4 & $537.33 \pm 138.17$ & $255.44 \pm 34.96$ & $478.22 \pm 38.1$ & $836.44 \pm 4.9$ \\
\hline \multirow{4}{*}{$\mathrm{SM}(\mathrm{mg} / \mathrm{l})$} & S1 & $74.88 \pm 21.46$ & $103.56 \pm 5.68$ & $104.47 \pm 19.23$ & $155.53 \pm 6.63$ \\
\hline & S2 & $73.88 \pm 23.19$ & $102.17 \pm 5.78$ & $96.44 \pm 23.03$ & $152.33 \pm 7.61$ \\
\hline & S3 & $71.22 \pm 26.35$ & $96.56 \pm 5.36$ & $89.88 \pm 20.37$ & $147.13 \pm 6.06$ \\
\hline & S4 & $60.81 \pm 18.38$ & $92.3 \pm 8.12$ & $73.81 \pm 12.54$ & $84.41 \pm 2.53$ \\
\hline \multirow{4}{*}{ CHLa $(\mu \mathrm{g} / \mathrm{l})$} & S1 & $17.1 \pm 13.53$ & $2.11 \pm 0.19$ & $40.19 \pm 24.94$ & $47.56 \pm 16.33$ \\
\hline & S2 & $17.82 \pm 15.75$ & $1.37 \pm 0.82$ & $30.41 \pm 29.72$ & $37.54 \pm 18.66$ \\
\hline & S3 & $13.64 \pm 10.03$ & $0.95 \pm 0.67$ & $28.62 \pm 24.88$ & $21.3 \pm 9.71$ \\
\hline & S4 & $9.52 \pm 4.59$ & $1.38 \pm 0.64$ & $19.89 \pm 29.4$ & $17.98 \pm 4.45$ \\
\hline
\end{tabular}

the research period for each of the four sites, are summarized in Tables 1 and 2.

The temperature data for water from the four sites were similar and ranged from $5.5^{\circ} \mathrm{C}$ to $24.5^{\circ} \mathrm{C}$ with the lower values found during the colder winter months $\left(<6^{\circ} \mathrm{C}\right.$ : $\mathrm{S} 1$ in February) and the highest in the autumn months $\left(>24^{\circ} \mathrm{C}\right.$ : $\mathrm{S} 4$ in September), as indicated in Table 1. Water in Messida canal was alkaline, with $\mathrm{pH}$ ranging from 7.1 to 8.8. The alkaline $\mathrm{pH}$ found in all sampling points was a situation representing that water was well buffered and in high trophic status ${ }^{\underline{11}}$. The $\mathrm{pH}$ of most freshwater systems is dependent on the mineral content of the surrounding rocks, soils and other landforms, and often ranges from 6 to 8 , which is ideal for most fish and plant species sup- ported by such ecosystems ${ }^{12}$. An important findings of the present study was that DO values were found lower than the standard $(<6.5 \mathrm{mg} / \mathrm{L})$ as described by ${ }^{\underline{13}}$.

The higher rate of saturation in dissolved oxygen is recorded in autumn, while the lowest value was found during spring and summer season (Table 1 ). $\mathrm{BOD}_{5}$ concentration ranged from $1.1 \pm 0.01 \mathrm{mg} / \mathrm{l}$ to $5.8 \pm 0.01 \mathrm{mg} / \mathrm{l}$ in all sampling points. The $\mathrm{DBO}_{5}$ in all sites was within limits recommended by JORA and $\mathrm{WHO}^{14,15}$. Significant $(\mathrm{P}<0.05)$ variations in $\mathrm{DO}, \% \mathrm{O} 2$ and $\mathrm{DBO}_{5}$ were found in all the four sampling time periods.

The higher EC and salinity values were mostly found at the S4 in summer (Table 1). Increasing EC and salinity during summer as a result of decreased dilution, increased 
Table 2. Geometric mean values of different nutrients of the collected samples (Mean \pm Standard Deviation)

\begin{tabular}{|c|c|c|c|c|c|}
\hline Parameters & Sites & Autumn & Winter & Spring & Summer \\
\hline \multirow{4}{*}{$\mathrm{NO}_{2}^{-}(\mathrm{mg} / \mathrm{l})$} & S1 & $0.84 \pm 0.07$ & $2.74 \pm 0.49$ & $1.07 \pm 0.32$ & $0.98 \pm 0.18$ \\
\hline & S2 & $0.84 \pm 0.06$ & $2.95 \pm 0.71$ & $1.1 \pm 0.28$ & $1.01 \pm 0.17$ \\
\hline & S3 & $0.79 \pm 0.06$ & $2.42 \pm 0.61$ & $1.17 \pm 0.003$ & $1.29 \pm 0.32$ \\
\hline & S4 & $0.78 \pm 0.06$ & $1.32 \pm 0.51$ & $1.14 \pm 0.05$ & $1.45 \pm 0.5$ \\
\hline \multirow{4}{*}{$\mathrm{NO}_{3}{ }^{-}(\mathrm{mg} / \mathrm{l})$} & S1 & $0.84 \pm 0.01$ & $0.03 \pm 0.03$ & $0.02 \pm 0.01$ & $3.4 \pm 2.03$ \\
\hline & $\mathrm{S} 2$ & $0.84 \pm 0.01$ & $0.04 \pm 0.02$ & $0.07 \pm 0.1$ & $0.11 \pm 0.08$ \\
\hline & S3 & $0.79 \pm 0.31$ & $0.04 \pm 0.02$ & $0.04 \pm 0.04$ & $0.34 \pm 0.32$ \\
\hline & S4 & $0.78 \pm 0.14$ & $0.01 \pm 0.004$ & $0.04 \pm 0.05$ & $0.02 \pm 0.02$ \\
\hline \multirow{4}{*}{$\mathrm{NH}_{4}{ }^{+}(\mathrm{mg} / \mathrm{l})$} & $\mathrm{S} 1$ & $0.19 \pm 0.03$ & $2.36 \pm 1.57$ & $4.41 \pm 2.23$ & $4.75 \pm 2.83$ \\
\hline & S2 & $0.13 \pm 0.09$ & $1.13 \pm 1.15$ & $4.01 \pm 1.73$ & $2.77 \pm 2.14$ \\
\hline & S3 & $0.09 \pm 0.06$ & $0.65 \pm 0.4$ & $1.27 \pm 0.2$ & $1.44 \pm 0.54$ \\
\hline & S4 & $0.18 \pm 0.04$ & $0.26 \pm 0.24$ & $1.28 \pm 0.21$ & $0.16 \pm 0.1$ \\
\hline \multirow{4}{*}{$\mathrm{PO}_{4}{ }^{3-}(\mathrm{mg} / \mathrm{l})$} & $\mathrm{S} 1$ & $2.66 \pm 2.15$ & $3.04 \pm 4.51$ & $13.19 \pm 0.81$ & $11.35 \pm 1.06$ \\
\hline & S2 & $2.23 \pm 0.74$ & $1.54 \pm 2.24$ & $13.42 \pm 0.96$ & $10.65 \pm 0.43$ \\
\hline & S3 & $5.25 \pm 2.78$ & $2.81 \pm 4.17$ & $11.53 \pm 0.7$ & $10.13 \pm 0.01$ \\
\hline & S4 & $5.36 \pm 2.57$ & $3.2 \pm 4.76$ & $8.5 \pm 1.27$ & $10.5 \pm 0.16$ \\
\hline
\end{tabular}

evaporation, and increased residence time ${ }^{16}$. The highest EC and Salinity at $\mathrm{S} 4$ as a result of marine intrusions. Classifying water quality in terms of EC, following irrigation water quality classifications for this parameter, allows to allocate all of the sampled points to the class 'Marginal' in winter $(\mathrm{EC}=90-270)$ and to the class 'Unacceptable' $(\mathrm{EC}>270)$ in the rest of the year of study. Fluctuations were found in different seasons showing statistically significance at $95 \%$ confidence level, fluctuations from autumn to winter, winter to summer, from spring to summer and from autumn to summer were found significant $(\mathrm{p}<0.05)$.

The TDS values of canal Messida waters were below the WHO permissible limit $1000 \mathrm{mg} / \mathrm{l}$. TDS and MS varied significantly between season samples (summer samples had higher TDS by $836.4 \pm 4.9$ and MS by $155.53 \pm 6.63$ 
$\mathrm{mg} / \mathrm{L}$, Kruskal-Wallis, $\mathrm{p}<0.05)$. These parameter MS varied significantly between sampling points $\left(\chi^{2}=27.65, \mathrm{df}=\right.$ $3, \mathrm{p}=0.00)$.

The chlorophyll- $a$ concentration varied between 0.15 and $91.67 \mu \mathrm{g} / \mathrm{l}$ and was highest at the station S2 in May. Mean $\mathrm{PO}_{4}^{3-}$ exceeds the permissible limit of $0.3 \mathrm{mg} / \mathrm{l}$ for each of the four impacts sites (S1-S4) (Table 2), and hence, the risk of eutrophication is not excluded in this canal ${ }^{17}$. On the basis of chlorophyll- $a$ and $\mathrm{PO}_{4}^{3-}$ values obtained during the study year, the canal Messida can be considered oligotrophic (low nutrient levels and no quality problems) on winter, mesotrophic (intermediate nutrient levels with emerging signs of quality problems) on autumn, and eutrophic (high nutrient levels and frequent quality problems) on spring and summer ${ }^{18}$.

The $\mathrm{NO}_{2}$ amounts were not low and do not change a lot along the sampling sites, varying between 0.74-3.87 $\mathrm{mg} / \mathrm{l}$. The nitrate concentrations at sites S1 and S2 (Table 2) exceeded the guideline for nitrate- $\mathrm{N}$ for protection of aquatic life from December to January $(>2.94 \mathrm{mg} / \mathrm{L})^{19}$. The high concentration of nitrates in surface water is the result of intensive agricultural activity or a contamination by human or animal wastes ${ }^{20}$. For the sites in the upstream (S1and S2), the canal Messida enrichment was also expressed by the highest values of $\mathrm{NH}_{4}^{+}: 5.05-8.97$ $\mathrm{mg} / \mathrm{l}$ during May and June. However, in the same periods, when continental influences decrease to the benefit of marine intrusions, $\mathrm{NH}_{4}{ }^{+}$concentrations are lower in the downstream sites (S3 and S4) (Table 2). Variation in nitrate and ammonium concentration along a canal assists in the identification of zones of intense pollution where detailed monitoring can be conducted. The relatively high nitrate and ammonium concentrations at sampling points located within horse stable (S1) and irrigation point (S2) indicated that these were the major sources of nitrate and ammonium pollution in the waters of canal Messida. High levels of nitrate contamination of waters in agricultural areas have been reported by various scholars from different parts of country $\underline{21-23}$. The contamination level for nitrite (Table 2) is generally exceed the concentrations guides for the aquatic life $(0.01 \mathrm{mg} / \mathrm{l})$ what classifies the waters of Messida canal in the bad quality.

\subsection{Indicators}

All data were transformed to $\log _{10}$ values for better interpretation.

TVBC, TC, FC, E. coli (EC), FS and RSS were detected in all sampling sites (Figure 2).

The TVBC data is generally taken as representative of the total microbial content including spoilage microorganism ${ }^{24}$.

The TVBC results for the four sites are ranged from $6.04 \log _{10}$ micro-organisms $/ 100 \mathrm{ml}$ to $7.28 \log _{10}$ microorganisms $/ 100 \mathrm{ml}$ of water. This higher value of TVBC has also been previously reported by ${ }_{-}^{25-27}$.

All sampling sites had TC, FC, and EC counts that indicated a negligible risk of infection to users from fecal contamination (Figure 2). Seasonal fluctuations were significant for all indicators $(\mathrm{P}<0.001)$, with the highest count for the TVBC, FC and EC were found in winter months (6.89, 5.9, $7.63 \log _{10}$ MPN /100ml respectively) followed by summer, autumn and spring months. It could be that the higher flow rates associated with heavy rainfall during the winter months could have led to higher coliform counts because of increased run-off from the informal settlement or re-suspension of bacteria from the river sediments $s^{28}$. A high fecal contamination of water was reported by Kulshrestha and authors of $29-31$.

FS was the only indicator that differed significantly between sampling sites $\left(\chi^{2}=21.70, \mathrm{df}=3, \mathrm{p}=0.00\right)$ with FS higher in summer by $4.9 \log _{10} \mathrm{MPN} / 100 \mathrm{ml}$ at $\mathrm{S} 1$ and S3 (Figure 2). The increase in FS count at S1 and S3 may be explained by the introduction of more bacteria by human activities, agricultural, and livestock. Sampling site $S 1$ is located near the headwaters of the main stream of Lac Tonga and a stable. Sampling site S3 is surrounded by agricultural land and a zone of pasture. The mean of EC, FS, and FC obtained from all sampling sites, on average exceeded the acceptable limit (Figure 2).

The count for the anaerobic spore formers ranged from 2.7 to $>2.8 \log _{10} \mathrm{CFU} / 100 \mathrm{~m} \ell$ in spring and summer. It was concluded that anaerobic spore formers of the Clostridium genus were present in the water. Although not all end spore formers are human pathogens, but 


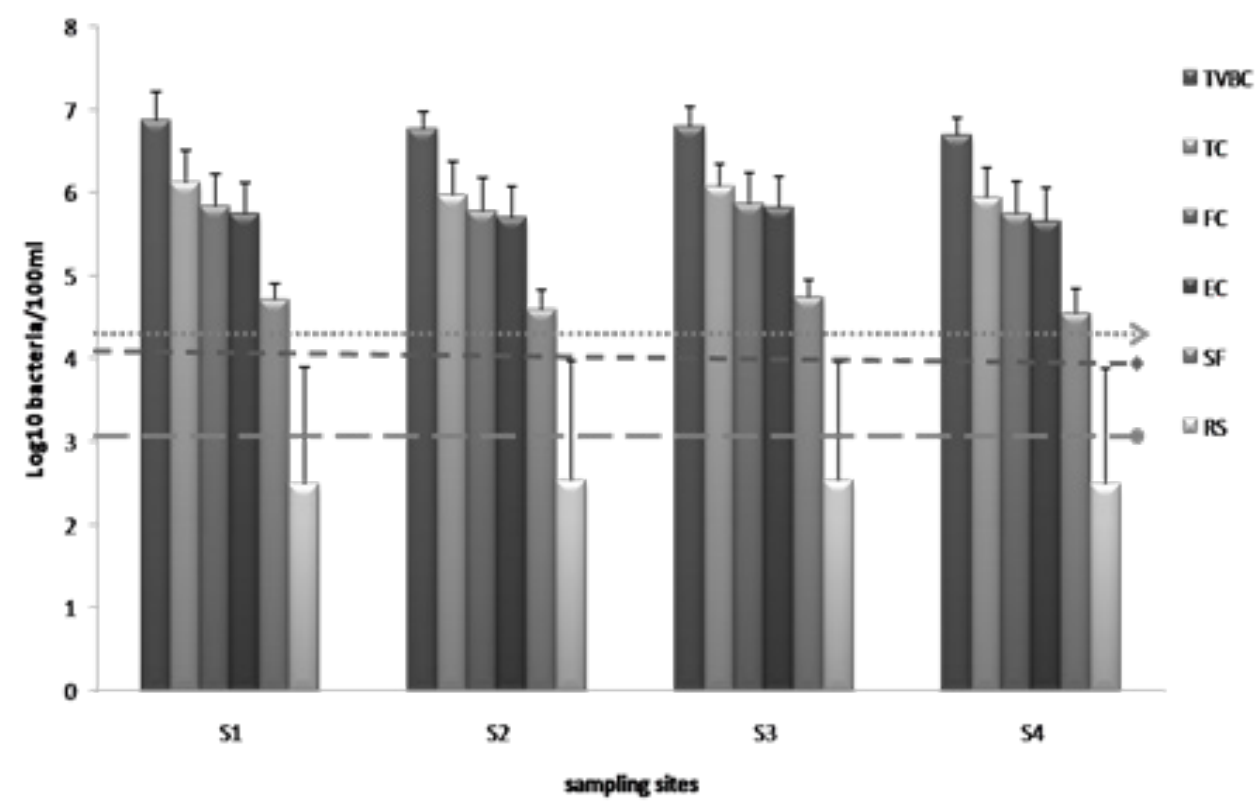

Figure 2. $\log _{10}$ mean microbial counts at sampling sites of Messida canal during September 2010 to August 2011. Horizontal lines represent maximum values of Escherichia coli (grey line with arrowhead), Fecal Streptococci (dark grey line with diamond head) of drinking water guidelines and maximum values of Fecal coliforms (grey line with rounded head) of irrigation water guidelines ${ }^{14}$.

Clostridium botulinum is important food borne pathogens $\frac{32}{2}$, and if irrigation water contained these it could lead to colonization and formation of biofilms on the surface of fresh produce ${ }^{33}$.

\subsection{Pathogens}

The presence of at least one pathogen, including Salmonella (SAL), Shigella (SHIG), Vibrio cholerae (VC),

Table 3. Prevalence of Salmonella, Shigella, Vibrio, Staphylococcus, Pseudomonas and Aeromonas among waters of canal Messida.

\begin{tabular}{|c|c|c|c|}
\hline & Species & P (\%) & Sampling site \\
\hline Salmonellae & S.typhimurium & 2.5 & S1 \\
\hline Shigellae & Shigella spp. & 2.5 & S1 \\
\hline Vibrios & V.cholerae & 2.5 & S1 \\
\hline Staphylococci & S.aureus & 5 & S3/S4 \\
& S.saprophyticus & 2.5 & S4 \\
\hline S.epidermidis & 5 & S2 \\
\hline Aeromonads & P.aeruginosa & 5 & S2 \\
\hline P.fluorescens & A.hydrophila & 70 & S1/S3/S4 \\
\hline
\end{tabular}


Aeromonas hydrophila (AH), Pseudomonas aeruginosa (PA) and/or Staphylococcus aureus (SA) was detected in all sampling sites of the Messida coastal canal (Table 3).

Contaminated surface water by bacterial pathogens is a major source of numerous waterborne disease outbreaks in the developing world ${ }^{34}$. In this study, multiple isolations of pathogens or opportunistic pathogens in Messida canal were not frequent, but human diseases and infections are often associated with several opportunistic human pathogens detected at low abundance ${ }^{35}$.

The isolates were dominated by Aeromonas hydrophila (Table 3). It is a Gram-negative ubiquitous aquatic bacterium, which has been isolated from a wide range of water sources, such as river water and drinking water $\frac{36-38}{}$. Some strains of AH are capable of causing septicemial in fish and amphibians as well as extra-intestinal and wound infections in human ${ }^{\frac{39}{}}$. An outbreak of $\mathrm{AH}$ wound infections associated with exposure to mud with river water has also been reported recently ${ }^{40}$.

Salmonella Typhimurium, Shigella spp. and VC were present in the water of S1. This is a clear indication that the survival of pathogens is possible in Messida canal. SA and PA are two important non enteric pathogens isolated from several water sources in addition to the fecal indicators that cause possible health risk ${ }^{41}$.

\subsection{Correlation and Principal Components Analysis}

Results of Spearman's product moment correlation analysis showed significant and strong correlation among some microbiological indicators. It was found that $\mathrm{FC}$ was positively correlated with EC $(r=0.97)$, TC was correlated with FC $\left(r_{=} 0.82\right)$. In addition, TC was correlated with EC $(r$ $0.80)$. On the other hand, negative correlation was also found between RS and TC, FC and EC respectively ( $r$ $\left.-0.43, r_{=}-0.35, r_{=}-0.32\right)$. Positive correlation among different fecal indicators in aquatic environment is a familiar scenario and the relationships among these indicators found in our study ultimately drew this known picture.

Principal components analysis (PCA) has been used as a tool for modeling linear relationships between biotic and abiotic variables to characterize the water quality of Messida canal. It is noteworthy that the different types of

Variables factor map (PCA)

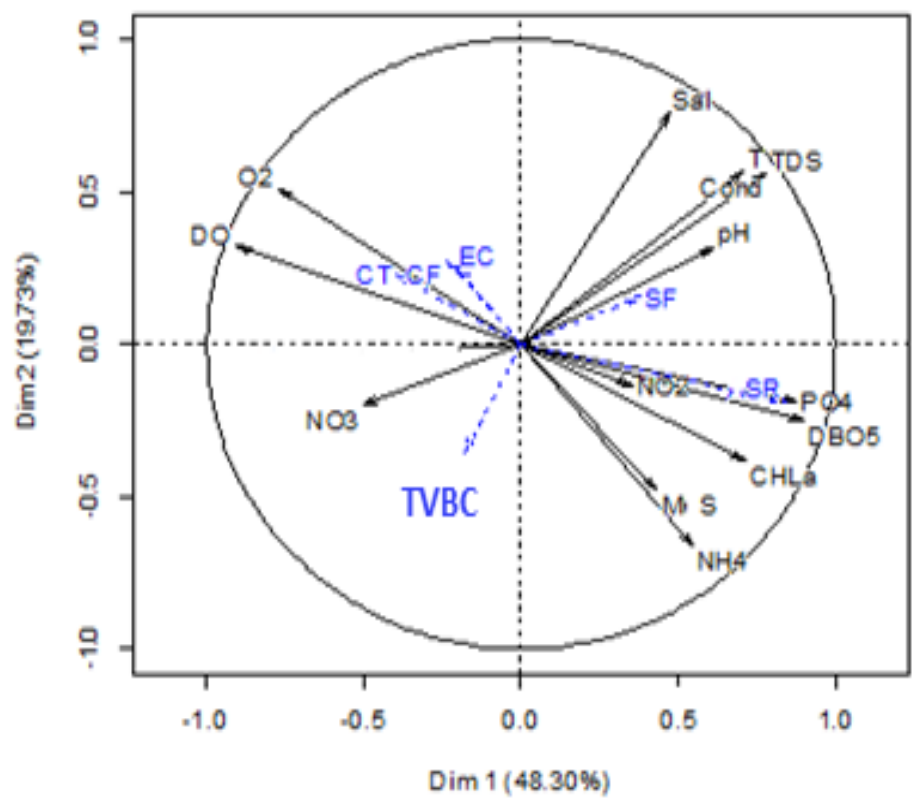

Figure 3. Correlation circles of the environmental variables with the two first axis of the standard PCA. 


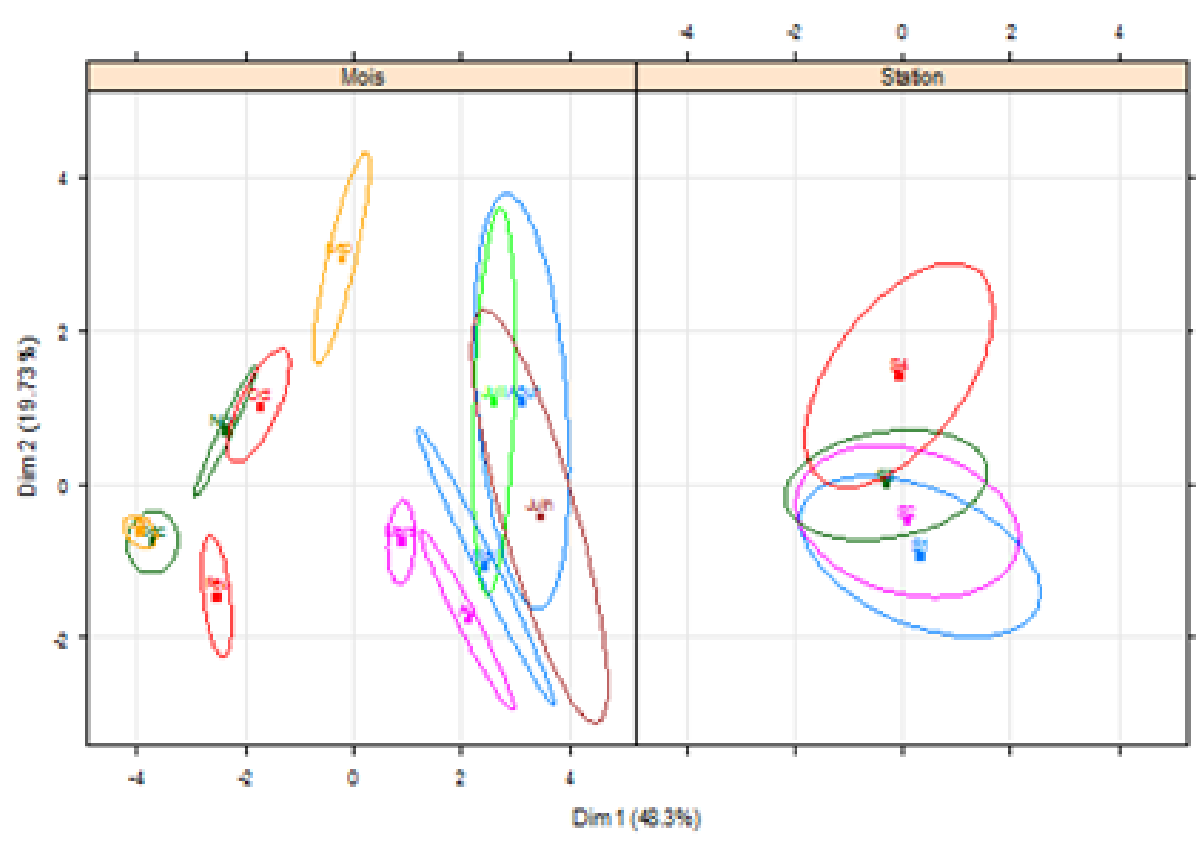

Figure 4. Sites and months projection on the two first main axis of the standard PCA.

germs counts were used as additional quantitative variables to achieve the PCA by the FactoMineR package.

The PCA clearly showed an inter-station and intermonth variation, where the two first factorial axes can explain together $68.03 \%$ of the total variation (Figures 3 and 4$)$.

The first axis explains $48.3 \%$ of the total variation; it is positively correlated with $\mathrm{DBO} 5$ variable $\left(r=0.89 ; \cos ^{2}=\right.$ $0.81), \mathrm{PO} 4\left(r=0.88 ; \cos ^{2}=0.77\right)$, SR $\left(r=0.84 ; \cos ^{2}=0.71\right)$, TDS $\left(r=0.78 ; \cos ^{2}=0.61\right)$, Cond $\left(r=0.78 ; \cos ^{2}=0.61\right)$, CHLa $\left(r=0.71 ; \cos ^{2}=0.51\right)$, and temperature $(r=0.71$; $\left.\cos ^{2}=0.5\right)$. This first axis has allowed us to group sites 1,2 , and 3. Quality of this water is characterized by high levels of nutrients, and fecal bacteria compared to station 4. This strong presence of nutrients and fecal contamination germs indicators in the upstream sites is explained by significant one-off punctual contributions (horse stable (S1), agricultural activities (S2), and pasture area (S3) in addition to diffuse inputs from the Tonga Lake.

The additional variable RS seems to be positively correlated with $\mathrm{DBO} 5$ and PO4. Calculation of the Spearman non-parametric correlation coefficient shows that this variable is positively correlated with BOD5 $(r=0.79)$ and the PO4 $(r=0.77)$. An increased RS counts when BOD5 and $\mathrm{PO} 4$ were higher is consistent with RS being sensitive to oxygenated conditions and having increased persistence in eutrophic water. Members of proteobacteria respond rapidly to organic and inorganic nutrient enrichment $\underline{42}$ and have been isolated from various polluted and unpolluted freshwater bodies 43,44 .

PCA results show that the first axis clearly demonstrates a significant effect of the variable DO on the TC $(r=0.62), \mathrm{FC}(r=0.50)$ and $\mathrm{EC}(r=0.47)$ in site 3 while the cold months. It is admitted that the DO is a physical parameter that determines the distribution of fecal indicators in the water especially in wet period; besides, cold water contains a bigger quantity of dissolved oxygen than a hot water $\frac{45}{}$.

A light positive correlation exists between the nitrate and bacteriological contamination (TVBC: $r=0.25$, FC: $r$ $=0.33$ and EC: $r=0.37$ ). The weak but significant correlation between nitrate and fecal bacteria may be indicative of recently generated surface water pollution from a rather local pollution source. Such an enrichment of the nutritional status of water may enhance the development of pathogenic bacteria. Nitrate contamination of surface 
water originates often from organic waste, and may therefore also be indicative of fecal contamination.

Axis 1 is of a clear difference between the group of the cold months (October, November, December, January and February) and the warmest months (March, April, May, June, July and August). This more or less seasonal structure could be explained by the strong positive correlations with this axis of $\mathrm{BDO} 5, \mathrm{PO} 4$ and SR variables; and by the strong negative correlation with $\mathrm{DO}(r=-0.91$; $\cos ^{2}=0.82$ ).

Axis 2, which explains $19.73 \%$ of the total variability, is essentially built by the salinity variable $\left(r=0.76 ; \cos ^{2}=\right.$ 0.58 ). This second axis divides station 4 from the rest of the stations. The coincidence of this 1:

Axis 2 allowed us to identify the specificity of September $\left(\cos ^{2}=0.78\right)$ compared to other months. Moreover, the additional variable FS on this axis seems to be positively correlated with $\mathrm{pH}(r=0.4)$, salinity $(r=0.4)$ and temperature $(r=0.4)$.

In environmental waters, Streptococci resist to harsh environmental conditions and persist longer in water than Coliforms ${ }^{46,47,51}$ report that levels of fecal streptococci are slightly influenced by variations in $\mathrm{pH}$ and salinity.

It is indicated that the high temperatures favor the survival of the fecal streptococci; on the other hand, they have a negative effect on $\mathrm{CF}^{52-55}$, fecal streptococci would have a high tolerance to high salinity of the sea; this would go in the sense of their use as indicator of fecal pollution in the marine environment.

Finally, the interpretation of the first two principal component axes enables the classification of the sites of Messida waters studied into tow hydrochemical groups (Figure 3 and 4):

Group 1: High bacterial and organic pollution waters (S1, S2, and S3);

Group 2: High mineralization waters (S4).

\section{Conclusion}

The data from this study clearly shows that the four sites on the Messida canal were polluted. Nutrient concentrations during this study were significantly elevated, being mesotrophic to eutrophic; critical threshold val- ues for nitrates, nitrite, $\mathrm{PO}_{4}^{3-}$ and electrical conductivity are exceeded in several sampled waters. The high TVBC, total coliform, fecal coliform, E.coli and fecal streptococci counts for all sampling sites indicate a continuously high level of microbial contamination. The presence of the indicator E. coli in all of the water samples evaluated, and the presence of fecal streptococci, confirms the type of pollution as being fecal. Agricultural run-off from farms adjacent to the canal Messida, human activities along the canal (agricultural, livestock) and the provision of Tonga waters could also have contributed to increased contaminant levels within the canal at all sampling sites.

The application of descriptive methods of Multivariate Data Analysis, such as PCA, has shown that this technique is an effective tool in the identification of the main structural interrelationships among the physico-chemical and bacteriological parameters of surface waters.

Statistical associations between microbes (i.e., TC, EC, RS, FS) and physico-chemical water quality variables (i.e., nitrate, $\mathrm{CHL}-a, \mathrm{PO}_{4}^{3-}$, $\mathrm{BOD}$, salinity) were observed in this study. While these results suggest that organism persistence is affected by canal water quality.

The results of this study indicate that Messida coastal canal water can be a path for contamination of swimmers with bacterial pathogens. In order to determine potential risks, a quantitative microbial risk assessment (QMRA) must be performed; this requires knowledge of pathogen concentration.

\section{References}

1. Shimmield G. Introduction to geochemistry of estuaries and coasts. Treatise on Estuarine and Coastal Science. Waltham: Academic Press. 2011; 4:1-8. https://doi.org/10.1016/B9780-12-374711-2.00401-0.

2. Agarwal T, Khillare PS, Shridhar V. PAHs contamination in bank sediment of the Yamuna River, Delhi, India. Environmental Monitoring and Assessment. 2006; 123(13):151-66. https://doi.org/10.1007/s10661-006-9189-6. PMid:16763739

3. Sinton LW, Finley RK, Hannah DJ. Distinguishing human from animal fecal contamination in water: A review. Zealand Journal of Marine and Freshwater Research. 1998; 32(2):323-48. https://doi.org/10.1080/00288330.1998.9516 828 
4. Nash D, Leeming R, Clemow L, Hannah M, Halliwell D, Allen D. Quantitative determination of sterols and other alcohols in overland flow from gazing land and possible source materials. Water Research. 2005; 39(13):2964-78. https:// doi.org/10.1016/j.watres.2005.04.063. PMid:15998530

5. Standard methods for the examination of water and wastewater. 20th Edition. American Water Works Association, Water Pollution Control Federation; 1998. p. 1-1220.

6. Aminot A, Kérouel R. Hydrologie des écosystèmes marins: paramètres et analyses = Marine ecosystem hydrology: parameters and analyses. Méthodes d'analyse en milieu marin. Editions IFREMER: Plouzané; 2004. p. 336.

7. Rejsek F. Analyse des eaux - Aspects réglementaires et techniques [Internet]. [cited 2002 Dec 01]. Available from: https://www.decitre.fr/livres/analyse-deseaux-9782866174200.html.

8. Rodier J. L'Analyse de l'eau - Eaux naturelles, eaux résiduaires, eau de mer [Internet]. [cited 2005 Oct 01]. Available from: https://www.decitre.fr/livres/l-analyse-del-eau-9782100496365.html/.

9. Ihaka R, Gentleman R. R: A language for data analysis and graphics. Computational and Graphical Statistics. 1996; 5(3):299-314. https://doi.org/10.1080/10618600.1996.104 74713.

10. Husson F, Josse J, Le S, Mazet J. FactoMineR: Multivariate exploratory data analysis and data mining with $\mathrm{R}$. R package version 1.27; 2014.

11. Bhatnagar A. Impact of mass bathing on water quality. International Journal of Environmental Research. 2009; 3(2):247-52.

12. Sampaio FG, boijink CL, Dos Santos LR. Oba ET, Kalinin AL, Rantin FT. The combined effect of copper and low $\mathrm{pH}$ on antioxidant defenses and biochemical parameters in neotropical fish pacu, Piaractus mesopotamicus (holmberg, 1887). Ecotoxicology. 2010; 19(5):963-76. https://doi. org/10.1007/s10646-010-0478-z. PMid:20213433

13. Lai YC, Tu YT, Yang CP, Surampalli RY, Kao CM. Development of a water quality modeling system for river pollution index and suspended solid loading evaluation. Journal of Hydrology. 2013; 478:89-101. https://doi. org/10.1016/j.jhydrol.2012.11.050

14. Official Journal of Algerian Republic (JORA). Executive decree $n^{\circ} 11-219$ Jun 12 th 2011 Setting the quality goals of superficial and ground waters intended for the water supply of the populations [Internet]. [cited 2014 Apr 09]. Available from: www.joradp.dz/FTP/jo-francais/2014/F2014013.pdf.

15. World Health Organization. Guidelines for drinking water quality. Incorporating the First and Second Addenda Recommendations. 3rd Edition. World Health Organization, Geneva; 2005. p. 1-668.
16. Lake S. Drought and aquatic ecosystems: Effects and responses. Wiley Blackwell, West Sussex, UK; 2011. p. 1-400. https://doi.org/10.1002/9781444341812.ins. PMCid:PMC5366243

17. Vyas A, Mishra DD, Bajapai A, Dixit S, Verma N. Environment impact of idol immersion activity lakes of Bhopal, India. Asian Journal of Experimental Sciences. 2006; 20(2):289-96.

18. Walmsley RD. Perspectives on eutrophication of surface waters: Policy/research needs in South Africa. Report No.KV129/00. Water Research Commission. Pretoria; 2000.

19. Canadian water quality guidelines for the protection of aquatic life. CCME (Canadian Council of Ministers of the Environment). nitrate Ion. Canadian Environmental Quality Guidelines, Winnipeg. 2003; 1:1-7.

20. Nas B, Berktay A. Groundwater contamination by nitrates in the city of Konya (Turkey): A GIS perspective. Journal of Environmental Management. 2006; 79(1):30-7. https://doi. org/10.1016/j.jenvman.2005.05.010. PMid:16143447

21. Berdai H. Lixiviation des nitrates et pollution des eaux souterraines en zones irriguées: Etude expérimentale et modélisation; Cas du Tadla. Thèse de Doctorat Es-sciences Agronomiques de l'IAV Hassan II, N8 d'ordre: EM/1/2003; 2003. p. 257.

22. Viau EJ, Goodwin KD, Yamahara KM, Layton BA, Sassoubre LM, Burns SL, Tong HI, Wonga SHC, Yuanan L, Boehm AB. Bacterial pathogens in Hawaii a coastal streams Associations with fecal indicators, land cover, and water quality. Water Research. 2011; 45(11):3279-90. https://doi. org/10.1016/j.watres.2011.03.033. PMid:21492899

23. Taner MU, Ustun B, Erdincler A. A simple tool for the assessment of water quality in polluted lagoon systems: A case study for Kuçukçekmece Lagoon, Turkey. Ecological Indicators. 2011; 11(2):749-56. https://doi.org/10.1016/j. ecolind.2010.08.003

24. Sela S. Fallik E. Microbial quality and safety of fresh produce. Postharvest Handling: A Systems Approach, 2nd Edition. Elsevier, New York; 2009. p. 351-98. https://doi. org/10.1016/B978-0-12-374112-7.00013-5.

25. Barnes JM. The impact of water pollution from formal and informal urban development's along the Plankenbrug River on water quality and health risk. PhD dissertation, University of Stellenbosch, Stellenbosch; 2003. p. 1-265.

26. Paulse AN, Jackson VA, Khan W. Comparison of microbial contamination at various sites along the Plankenburg and Diep Rivers, Western Cape, South Africa. Water SA. 2009; 35(4):469-78. https://doi.org/10.4314/wsa.v35i4.76808.

27. Gemmell ME, Schmid TS. Microbiological assessment of river water used for the irrigation of fresh produce in a suburban community in Sobantu, South Africa. Food Research 
International. 2012; 47:300-5. https://doi.org/10.1016/j. foodres.2011.07.016.

28. Dukta BJ, Kwan KK. Bacterial die-off and stream trans $\neg$ port studies. Water Research. 1980; 14(7):909-15. https://doi. org/10.1016/0043-1354(80)90273-0.

29. Kulshrestha H, Sharma S. Impact of mass bathing during Ardhkumbh on water quality status of river Ganga. Journal of Environmental Biology. 2006; 27(2):437-40. PMid:17436540

30. Telang S, Saxena Y, Chaturvedi A. Effect of mass bathing on the water quality of Narmada River at district Hoshangabad, (M.P.) India. Current World Environment. 2009; 4(1):2113. https://doi.org/10.12944/CWE.4.1.37.

31. Ackermann A. Assessment of microbial loads of the Plankenburg and Berg Rivers and the survival of Escherichia coli on raw vegetables under laboratory conditions. M.Sc Food Science Thesis, Stellenbosch University, Stellenbosch, South Africa; 2010. p. 1-131.

32. Kim JB, Jeong HR, Park YB, Kim JM, OH D. Food poisoning associated with emetic-type of Bacillus cereus in Korea. Foodborne Pathogens and Disease. 2010; 7(5):555-63. https://doi.org/10.1089/fpd.2009.0443. PMid:20446859

33. Niemera BA, Cooke PH. Escherichia coli O157: H7 biofilm formation on Romaine lettuce and spinach leaf surfaces reduces efficacy of irradiation and sodium hypochlorite washes. Journal Food Science. 2010; 75(5):270-7. https:// doi.org/10.1111/j.1750-3841.2010.01650.x. PMid:20629883

34. Tao R, Guang-GuoY, Hao-Chang S, Hong-Wei Z, Jatinder PSS. Detection of antibiotic resistance and tetracycline resistance genes in Enterobacteriaceae isolated from the Pearl rivers in South China. Environmental Pollution. 2010; 158(6):2101-9. https://doi.org/10.1016/j. envpol.2010.03.004. PMid:20356660

35. Mahlen SD. Serratia infections: from military experiments to current practice. Clinical Microbiology Reviews. 2011; 24(4):755-91. https://doi.org/10.1128/CMR.00017-11. PMid:21976608 PMCid:PMC3194826

36. Lynch MJ, Swift S, Kirke DF, Keevil CW, Dodd CE, Williams $\mathrm{P}$. The regulation of biofilm development by quorum sensing in Aeromonas hydrophila. Environmental Microbiology. 2002; 4(1):18-28. https://doi.org/10.1046/ j.1462-2920.2002.00264.x. PMid:11966822

37. Bomo AM, Storey MV, Ashbolt NJ. Detection, integration and persistence of aeromonads in water distribution pipe biofilms. Journal of Water Health. 2004 ; 2(2):83-96. https://doi.org/10.2166/wh.2004.0008. PMid:15387132

38. Canals R, Altarriba M, Vilches S, Horsburgh G, Shaw JG, Tomás JM, Merino S. Analysis of the lateral flagellar gene system of Aeromonas hydrophila AH-3. Journal of Bacteriology. 2006; 188(3):852-62. https://
doi.org/10.1128/JB.188.3.852-862.2006. PMid:16428388 PMCid:PMC1347325

39. Fernandez MC, Giampaolo BN, Ibanez SB, Guagliardo MV, Esnaola MM, Conca L, Valdivia P, Stagnaro SM, Chiale C, Frade H. Aeromonas hydrophila and its relation with drinking water indicators of microbiological quality in Argentine. Genetica. 2000; 108(1):35-40. https://doi. org/10.1023/A:1004025907858. PMid:11145418

40. Vally H, Whittle A, Cameron S, Dowse G.K, Watson T. Outbreak of Aeromonas hydrophila wound infections associated with mud football. Clinical Infectious Diseases. 2004; 38(8):1084-9. https://doi.org/10.1086/382876. PMid:15095211

41. Fleisher J, Kay D, Salmon R, Jones F, Wyer M, Godfree A. Marine waters contaminated with domestic sewage: non enteric illnesses associated with bather exposure in the United Kingdom. American Journal of Public Health. 1996; 86:1228-34. https://doi.org/10.2105/AJPH.86.9.1228. PMid:8806373. PMCid:PMC1380584

42. Hahn MW. Isolation of strains belonging to the cosmopoli $\neg$ tan Polynucleobacter necessarius cluster from freshwater habitats located in three climatic zones. Applied and Environmental Microbiology. 2003; 69(9):5248-54. https://doi.org/10.1128/AEM.69.9.5248-5254.2003. PMid:12957910. PMCid:PMC194981

43. De Figueiredo DR, Ferreira RV, Cerqueira M, De Melo TC, Pereira MJ, Castro BB, Correia A. Impact of water quality on bacterioplankton assemblage along Cértima River Basin (central western Portugal) assessed by PCR-DGGE and multivariate analysis. Environmental Monitoring and Assessment. 2011; 184(1):471-485. https://doi.org/10.1007/ s10661-011-1981-2. PMid:21431313

44. Haller L, Tonolla M, Zopfi J, Peduzzi R, Wildi W, Poté J. Composition of bacterial and archaeal communities in freshwater sediments with different contamination levels (Lake Geneva, Switzerland). Water Research. 2011; 45(3):121328. https://doi.org/10.1016/j.watres.2010.11.018. PMid:21145090

45. Hébert S, Légaré S. Suivi de la qualité de l'eau des rivières et petits cours d'eau. Direction du suivi de l'état de l'environnement. Ministère de l'Environnement Gouvernement du Québec; 2000. p. 1-48.

46. Evison LM. Comparative studies on the survival of indicator organisms and pathogens in fresh and seawater. Water Science Technology. 1989; 20(11-12):309-15. https://doi. org/10.2166/wst.1988.0300.

47. Gleeson C, Gray N. The coliform index and waterborne disease [electronic resource]: Problems of microbial drinking water assessment. London: New York: E \& FN SPON; 1997. p. 194. 
48. Rozen Y, Belkin S. Survival of enteric bacteria in seawater . FEMS Microbiology Reviews. 2001; 25(5):513-29. https://doi.org/10.1111/j.1574-6976.2001.tb00589.x. PMid:11742689

49. Elsas V, Semenov JD, Costa AVR, Trevors JT. Survival of Escherichia coli in the environment: Fundamental and public health aspects. The ISME Journal. 2010; 5(2):17383. https://doi.org/10.1038/ismej.2010.80. PMid:20574458. PMCid:PMC3105702

50. Chigbu P, Gordon S, Strange TR. Fecal coliform bacteria disappearance rates in a north-central Gulf of Mexico estuary. Coastal and Shelf Science. 2005; 65(1-2):309-18. https://doi.org/10.1016/j.ecss.2005.05.020.

51. Garrido-Perez MC, Anfuso E, Acevedo A, PeralesVargas-Machuca JA. Microbial indicators of faecal contamination in waters and sediments of beach bathing zones. International Journal of Hygiene and Environmental Health. 2008; 211(5-6):510-17. https://doi.org/10.1016/j. ijheh.2007.09.010. PMid:18248849

52. Aslan-Yilmaz A, Okus E, Övez S. Bacteriological indicators of anthropogenic impact prior to and during the recovery of water quality in an extremely polluted estuary, Golden Horn, Turkey. Marine Pollution Bulletin. 2004; 49(11-12):951-8. https://doi.org/10.1016/j.marpolbul.2004.06.020. PMid:15556180

53. Sinton L, Hall C, Braithwaite R. Sunlight inactivation of Campylobacter jejuni and Salmonella enterica, compared with Escherichia coli, in seawater and river water. Journal of Water Health. 2007; 5(3):357-65. https://doi.org/10.2166/ wh.2007.031. PMid:17878550

54. Blaustein RA, Pachepsky Y, Hill RL, Shelton DR, Whelan G. Escherichia coli survival in waters: Temperature dependence. Water Research. 2013; 47(2):569-78. https://doi. org/10.1016/j.watres.2012.10.027. PMid:23182082

55. Bordalo AA, Onrassami R, Dechsakulwatana C. Survival of fecal indicator bacteria in tropical estuarine waters (Bangpakong River, Thailand). Journal of Applied Microbiology. 2002; 93(5):864-71. https://doi.org/10.1046/ j.1365-2672.2002.01760.x. PMid:12392534 